\title{
Zircon U-Pb ages from an ultra-high temperature metapelite, Rauer Group, east Antarctica: Implications for overprints by Grenvillian and Pan-African events
}

\author{
Yanbin Wang, ${ }^{1}$ Laixi Tong, ${ }^{2}$ and Dunyi Liu ${ }^{1}$ \\ ${ }^{1}$ Beijing SHRIMP Center, Institute of Geology, Chinese Academy of Geological Science, Baiwanzhuang Rd, No.26, Beijing, 100037, China \\ (yanbinw@ cags.net.cn) \\ ${ }^{2}$ Institute of Earth Sciences, Academia Sinica, Taipei 115, Taiwan, China (tong@ earth.sinica.edu.tw)
}

\begin{abstract}
SHRIMP U-Pb dating of zircon from an ultra-high temperature (UHT, $\sim 1000{ }^{\circ} \mathrm{C}$ ) granulite-facies metapelite from the Rauer Group, Mather Peninsula, east Antarctica, has yielded evidence for two episodes of metamorphic zircon growth, at $\sim 1.00 \mathrm{Ga}$ and $\sim 530 \mathrm{Ma}$, and two episodes of magmatism in the source region for the protolith sediment, at $\sim 2.53$ and $\sim 2.65 \mathrm{Ga}$, were identified from the zircon cores. Successive zircon growth at $\sim 1.00 \mathrm{Ga}$ and $\sim 530 \mathrm{Ma}$ records a sequence of distinct, widely spaced high-temperature metamorphic and/or anatectic events related to Grenvillian and Pan-African orogenesis. This study presents the first robust geochronological evidence for the timing of UHT metamorphism of the Rauer Group, supporting arguments that the peak UHT metamorphic event occurred at $\sim 1.00 \mathrm{Ga}$ and was overprinted by a separate high-grade event at $\sim 530 \mathrm{Ma}$. The new age data indicate that the UHT granulites of the Rauer Group experienced a complex, multi-stage tectonothermal history, which cannot simply be explained via a single Pan-African ( $\sim 00 \mathrm{Ma}$ ) high-grade tectonic event. This is critical in understanding the role of the eastern Prydz Bay region during the assembly of the east Gondwana supercontinent, and the newly recognized inherited Archaean ages $(\sim 2.53$ and $\sim 2.65 \mathrm{Ga}$ ) suggest a close tectonic relationship between the Rauer Group and the adjacent Archaean of the Vestfold Hills.
\end{abstract}

Citation: Wang Yanbin, Laixi Tong, and Dunyi Liu, 2007, Zircon U-Pb ages from an ultra-high temperature metapelite, Rauer Group, east Antarctica: Implications for overprints by Grenvillian and Pan-African events, in Antarctica: A Keystone in a Changing World -Online Proceedings of the 10 ${ }^{\text {th }}$ ISAES, edited by A. K. Cooper and C. R. Raymond et al., USGS Open-File Report 2007-1047, Short Research Paper 023, 4 p.; doi:10.3133/of2007-1047.srp023.

\section{Introduđion}

The ultra-high temperature (UHT) metamorphic granulites of the Rauer Group on the Mather Peninsula (Fig. 1) provide an important window into understanding the geological histories of the complex high-grade terranes of eastern Prydz Bay, east Antarctica. However, the age of ultra-high temperature granulite-facies metamorphism in the Rauer Group remains controversial (e.g. Harley et al., 1998). Whether the peak UHT granulite assemblages formed in the late Proterozoic (Grenvillian) event at $\sim 1.00 \mathrm{Ga}$ (Harley et al., 1998; Tong and Wilson, 2006) or in the early Palaeozoic (PanAfrican) tectonic event at $\sim 530$ Ma (Harley, 2003; Kelsey et al., 2003) has not yet been determined. The Mather Paragneiss is commonly considered to preserve evidence of an older, more extreme granulite-facies event than other rock types "in the Rauer Group (Harley and Fitzsimons 1991). Although the sapphirine-bearing Mather paragneiss bears a clear metamorphic imprint of Pan-African orogenesis at $\sim 511 \mathrm{Ma}$ (Kelsey et al., 2003), whether the UHT event occurred at $\sim 500 \mathrm{Ma}$ or $\sim 1.00 \mathrm{Ga}$ is still debated. The timing of the major orogenic events that affected the UHT metapelites has not yet been clearly defined, and their pre-Pan-African history remains obscure. Here we present new SHRIMP ion probe zircon $\mathrm{U}-\mathrm{Pb}$ ages from a sample of sapphirinebearing, granulite facies metapelite from the Mather Peninsula that show evidence of two metamorphic episodes. The pre-Pan-African geologic history preserved in this rock correlates with other parts of the East Antarctic shield and reveals both $\sim 2.53$ and $\sim 2.65$
Ga magmatic activity in the source region of the protolith sediment.

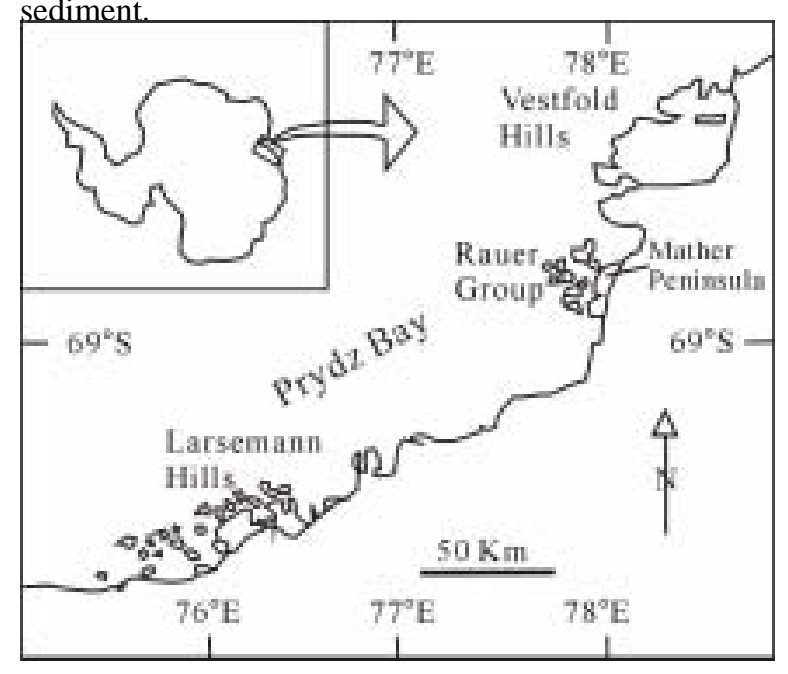

Figure. 1 Location of the Rauer Group within Prydz Bay, showing the Mather Peninsula within the eastern Rauer Group.

\section{Geological setting}

The Mather paragneiss comprises a variety of rock types (Harley et al., 1998) hosted by felsic orthogneiss that outcrop discontinuously as a gneissosity-parallel unit over a strike length of $3 \mathrm{~km}$ in the eastern Rauer Group. UHT $\left(1030{ }^{\circ} \mathrm{C}\right)$ metamorphism is recorded in the Rauer Group at Mather Peninsula by the stability of Mg-rich orthopyroxene + garnet + sillimanite assemblages that are sequentially overprinted by sapphirine-and cordieritebearing mineral reaction textures (Harley, 2003). High- 
temperature sapphirine-bearing metamorphic assemblages are preserved in the high-strain zone of the Rauer Group and are overprinted by retrograde biotitecordierite-bearing assemblages that Kelsey et al. (2003) attributed to early Palaeozoic ( 511 Ma) orogenesis.

The Archaean in the Rauer Islands is dominated by $>3.30 \mathrm{Ga}$ and $~ 2.84-2.80 \mathrm{Ga}$ orthogneisses (Kinny et al., 1993; Harley et al., 1998). These gneisses, extensively dyked and then deformed again by younger events, are interleaved with Mesoproterozoic metasediments and 1.03-1.00 Ga felsic to mafic intrusives that have also experienced high-grade metamorphism. Despite the extensive isotopic evidence for high-grade metamorphism in the Rauer Islands at $\sim 530 \mathrm{Ma}$ (Hensen $\&$ Zhou, 1995; 1997), the preservation of monazite U-Pb ages near $1.00 \mathrm{Ga}$ in the metasedimentary gneisses of the Filla Supracrustals confirm the importance of the $\sim 1.00$ Ga event ( Kinny, 1998). The $\sim 1.00 \mathrm{Ga}$ isotopic record in this domain is associated with granulite facies metamorphism and deformation. Garnet-matrix Sm-Nd mineral isochrons from two closely-spaced (within $10 \mathrm{~m}$ ) samples of the Mather Paragneiss yielded ages of 600 and $485 \mathrm{Ma}$, which have been interpreted as being close to the age of garnet formation in these samples (Hensen \& Zhou, 1995). Harley et al. (1998) concluded that the ultra-high temperature near-isothermal decompression may reflect either a temporally unrelated tectonic event (e.g. Archaean) or just an early stage of a single event at either $\sim 1.00 \mathrm{Ga}$ or $\sim 500$ Ma. Hokada \& Harley.(2003) reported electron microprobe chemical ages of monazites from Mather UHT gneisses, 580-450Ma, with minor $\sim 700 \mathrm{Ma}$ inheritance. They also obtained low precision electron microprobe chemical ages of zircons, the preliminary analyses suggest preservation of lateArchaean protolith zircons, $\sim 1.0 \mathrm{Ga}$, but few zircons in the 580-450 Ma age range determined for the monazites in the same rocks and textural microdomains. Kelsey et al. (2003) argued, however, that the ultra-high temperature event was associated with a single $\sim 500 \mathrm{Ma}$ tectonic event.

\section{SHRIMP U-Pb results}

Sample R1 is a coarse-grained sapphirine-biotite gneiss from Mather Peninsula in the eastern Rauer Islands. The region consists of heterogeneous gneisses, including felsic orthogneiss, enderbitic gneiss, felsicmafic composite gneiss, fosterite marble, leucogranitic orthogneiss, and mafic or ultramafic orthogneiss ( Harley, 1998). Sample R1 contains orthopyroxene, garnet, sillimanite, sapphirine, cordierite, K-feldspar, biotite, and minor plagioclase with accessory monazite and zircon. The highest grade metamorphic conditions recorded from comparable samples at this locality are about 11-12 kbar and $1033 \pm 30^{\circ} \mathrm{C}$ (Harley, 1998).

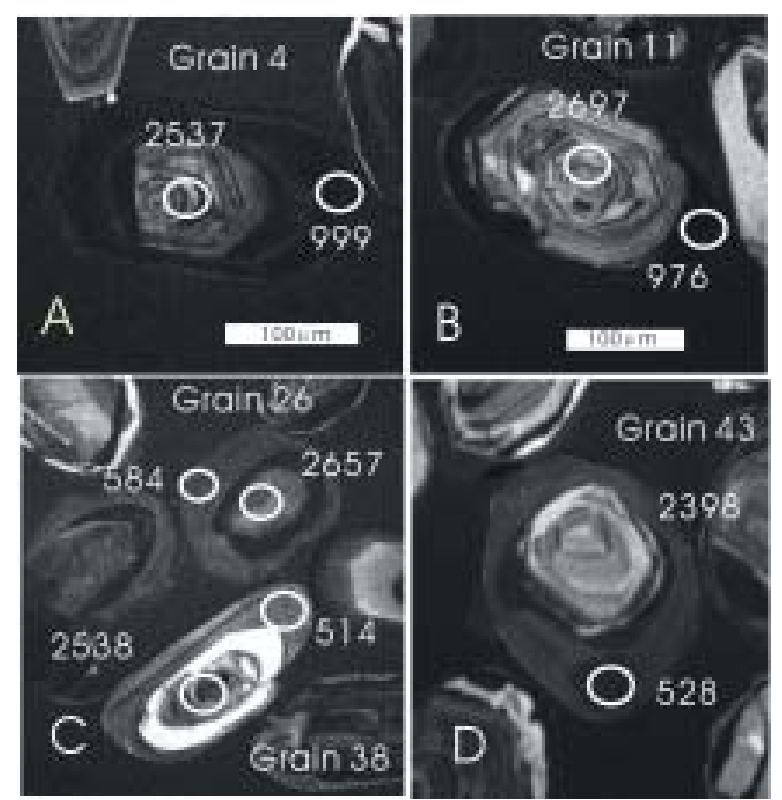

Figure. 2 Cathodoluminescence (CL) images of representative zircons from R1, showing locations and sizes of analysis areas. Each analyzed grain shows $\mathrm{U}-\mathrm{Pb}$ age in Ma (generally ${ }^{207} \mathrm{~Pb} /{ }^{206} \mathrm{~Pb}$ age for $>800 \mathrm{Ma}$, and ${ }^{206} \mathrm{~Pb} /{ }^{238} \mathrm{U}$ age for $<800 \mathrm{Ma}$ zircons. A \& B: Grain 4 and Grain 11, showing Archaean cores with igneous growth banding, and Proterozoic overgrowths ( 999 and $976 \mathrm{Ma}$ on the spots in grain 4 and 11 are $100 \%$ and $98 \%$ concordant). C: Scale is the same as for A and B. Grains 26, 38 and 43, showing Pan-African overgrowths on Archaean cores. Grain 43 core analysis yielded a slightly discordant age of $2398 \pm 10 \mathrm{Ma}$. Minor Pb-loss was seen in the grain 38 overgrowth analysis.

The SHRIMP U-Pb analytical procedures followed those outlined by Williams (1998) and references therein. Standard techniques were used to separate zircons and prepare a sectioned epoxy disk with representative grains from R1 and the TEM reference zircon (Black et al., 2003). Cathodoluminescence (CL) images were used to identify zircon crystal domains (Fig. 2).

Forty seven individual zircon grains from R1 were analysed during a single extended SHRIMP session. Most grains consisted of discrete centers with overgrowths, yielding 74 individual U-Pb ages (Fig. 3). Uncertainties for individual analyses are quoted at the $1 \sigma$ level. All age calculations are given with uncertainties at $95 \%$ confidence levels.

\section{Archaean zircon cores}

Most of the zircons have distinct cores, typically equant or prismatic domains with faceted to rounded shapes. Their internal growth structure includes oscillatory zoning (Fig. 2A, grain 4 and 11), which is common in igneous zircons. Analyses of cores yielded two main age populations (Fig. 2): one with a weighted mean ${ }^{207} \mathrm{~Pb} /{ }^{206} \mathrm{~Pb}$ age of $2657 \pm 17 \mathrm{Ma}(2 \sigma, \mathrm{n}=8)$ and $\mathrm{a}$ 
second with a weighted mean ${ }^{207} \mathrm{~Pb} /{ }^{206} \mathrm{~Pb}$ age of $2532 \pm$ $12 \mathrm{Ma}(2 \sigma, \mathrm{n}=14)$. These ages reflect the crystallization of an igneous parent. The clustered ages may reflect two magmatic episodes, at $\sim 2.65$ and $\sim 2.53 \mathrm{Ga}$, suggesting that eroding igneous rocks of this age were the source for the protolith of the metapelite. The similarity of these ages to the $2526 \mathrm{Ma}$ age of the Mossel gneiss (Black et al., 1991; Snape et a., 1997) in the Vestfold Hills $20 \mathrm{~km}$ north of the Rauer Group suggests that this Archaean magmatism produced primary, juvenile crust in the East Antarctic Shield.
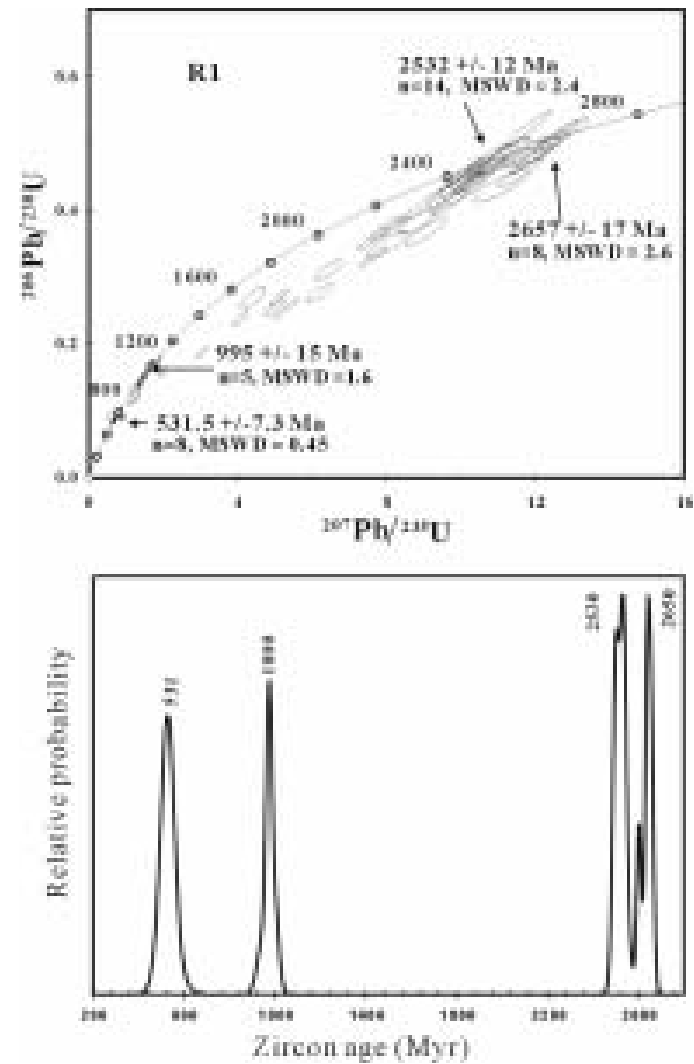

Figure. 3 Concordia diagram for sample R1 zircons (Uncertainties are $1 \quad \sigma)$ and Probability density distribution of SHRIMP zircon U-Pb ages (35 analyses ${ }^{95}-105 \%$ concordance). Generally ${ }^{207} \mathrm{~Pb} /{ }^{206} \mathrm{~Pb}$ age for $>800 \mathrm{Ma}$, and ${ }^{206} \mathrm{~Pb} /{ }^{238} \mathrm{U}$ age for $<800 \mathrm{Ma}$ zircons.

\section{Grenvillian age ( 1.00 Ga) overgrowths}

Distinctive zircon that has weak CL and is either texturally homogeneous or weakly sector zoned occurs as wide overgrowths on the Archaean cores (Fig. 2A and $2 \mathrm{~B}$, grains 4,11$)$. The overgrowths cover cores with slightly round external shapes, suggesting topotactic growth on a primary core. The absence of oscillatory zoning and very low $\mathrm{Th} / \mathrm{U}$ (average 0.02 ) are consistent with metamorphic zircon growth.

Analyses of such overgrowths yielded a weighted mean ${ }^{207} \mathrm{~Pb} /{ }^{206} \mathrm{~Pb}$ age of $995 \pm 15 \mathrm{Ma}$ (e.g. Grain 4 , spot 4.2 core: ${ }^{207} \mathrm{~Pb} /{ }^{206} \mathrm{~Pb}$ age, $2537 \pm 13 \mathrm{Ma}, \mathrm{Th} / \mathrm{U}=0.57$; $4.1 \mathrm{rim}:{ }^{206} \mathrm{~Pb} /{ }^{238} \mathrm{U}$ age, $999 \pm 18 \mathrm{Ma}, \mathrm{Th} / \mathrm{U}=0.01,100 \%$ concordant), with some discordance toward 530 Ma. Many analyses yielded highly discordant compositions that reflect significant $\mathrm{Pb}$ loss $\sim 1.00 \mathrm{Ga}$ and/or $530 \mathrm{Ma}$. Those domains were wide overgrowths on Archaean cores with prismatic external terminations. The scale, morphology, and internal texture of these overgrowths indicate that the $1.00 \mathrm{Ga}$ event involved new metamorphic grain growth, as opposed to anatexis or recrystallization, because (1) oscillatory growth zoning is absent; (2) Th/U ratios are distinct and low, with the overgrowths having $\mathrm{Th} / \mathrm{U}$ values $(0.01-0.02)$ that are considered to be consistent with a metamorphic rather than a magmatic origin $(\mathrm{Th} / \mathrm{U}>0.1$; Williams et al., 1996). The $1.00 \mathrm{Ga}$ domains may therefore reflect hightemperature heating during crustal orogenesis.

\section{Pan-African age ( 530 Ma) overgrowths}

The two types of texturally 'young' zircon overgrowths are found on many grains. First type of zircon comprises spheroidal to ellipsoidal grains (Fig.2 C \& D, grains 26, 43). In CL, these grains comprise a resorbed core of oscillatory-zoned, zircon mantled by darked rim, too thin to analyse, possibly similar to the $\sim 1.00 \mathrm{Ga}$ overgrowths, succeeded outwards by wide outer rims that have high $\mathrm{Th} / \mathrm{U}$ values $(\mathrm{Th} / \mathrm{U}>0.2)$. Eight analyses of these outer rims have yielded a weighted mean ${ }^{206} \mathrm{~Pb} /{ }^{238} \mathrm{U}$ age of $532 \pm 7 \mathrm{Ma}$. This is interpreted to reflect new zircon growth at ca. $530 \mathrm{Ma}$ related to the crystallization of melts. Their occurrence on rounded or embayed mantles, indicating crystallization on dissolution surfaces formed by partial melting (Vavra et al., 1999). The second type of texturally 'young' zircon overgrowth occurs on stubby-to elongate grains (Fig.1C, grain 38). These overgrowths are moderately luminescent and show oscillatory zoning over brighter zircon mantles. The oscillatory-zoned overgrowths have high $\mathrm{Th} / \mathrm{U}$ values $(\mathrm{Th} / \mathrm{U}>0.3)$ and yield ca. 530Ma ages that again are inferred to date magmatic crystallization associated with Pan-African thermotectonic activity in the region (Carson et al., 1996).

\section{Discussion and conclusions}

Using the Sensitive High Resolution Ion Microprobe (SHRIMP) zircon $\mathrm{U}-\mathrm{Pb}$ dating technique, we have obtained multiple zircon ages from a UHT sapphirinebearing metapelite from the Rauer Group, Mather Peninsula, east Antarctica, which we attribute to four geologic events between $\sim 2.65 \mathrm{Ga}$ and $530 \mathrm{Ma}$. The zircon cores record two igneous episodes, at 2.53 and $2.65 \mathrm{Ga}$, and the mantles and rims two metamorphic episodes at $\sim 1.00 \mathrm{Ga}$ and $530 \mathrm{Ma}$, respectively. This is the first evidence recognized in the Rauer Islands for an age similar to that of the $2.53 \mathrm{Ga}$ Mossel gneiss in the adjacent Vestfold Hills. The new data suggest that Vestfold Hills and Rauer Group terranes were possibly amalgamated in the Archaean.

The zircon overgrowths on Archaean cores represent metamorphic and/or anatectic modifications to these 
rocks at $\sim 1.00 \mathrm{Ga}$ and $530 \mathrm{Ma}$. Wide overgrowths of both ages reflect substantial new zircon growth at high temperatures. There is no doubt that the UHT metapelite was subjected to Grenville and Pan-African overprints at $\sim 1.00 \mathrm{Ga}$ and $530 \mathrm{Ma}$. Our data are the first to conclusively identify a period of Grenville metamorphism in UHT metapelite of the Rauer Group, and they correspond closely to SHRIMP ages from felsic orthogneiss from Filla Island (Kinny et al., 1993). The $\sim 1.00 \mathrm{Ga}$ overgrowths have $\mathrm{Th} / \mathrm{U}$ of $0.01-0.02$, suggesting a metamorphic rather than a magmatic origin (Williams et al., 1996). These data reveal an important period of orogenic activity $\sim 1.00 \mathrm{Ga}$ which we interpret to have been the UHT metamorphic event that affected the sapphirine-bearing metapelite. We think that the ultrahigh temperature event may be intimately associated with the enderbitic magmatism. The ultrahigh temperature event may have occurred during the c. 1.00 $\mathrm{Ga}$, synchronously with the enderbitic magmatism. The enderbitic orthogneiss hosting the Mather paragneiss could be late Mesoproterozoic, as an identical enderbitic orthogneiss on Macey peninsula is late Mesoproterozoic ( c. $1.0 \mathrm{Ga}$ ) (Tong et al., 2006). Given that the Fe-Al-rich metapelite represents part of Filla paragneiss, the Filla and Mather paragneisses have been suggested to have had a shared P-T history ( Tong \& Wilson, 2006), while the former is commonly hosted by the c.1.0 Ga felsic orthogneiss, and may have experienced granulite metamorphism at c. $1.0 \mathrm{Ga}$ ( Kinny, et al., 1993; Kinny, 1998), Whereas the ( Th-U)-Pb monazite age of PanAfrican directedly retrieved from symplectic and coronal textures ( Kelsey, 2003) maybe associated with post-peak decompression-cooling and retrograde metamorphism during the Pan-African age tectonic event.

We interpret the $530 \mathrm{Ma}$ overgrowths with igneous oscillatory growth zoning as recording magmatic crystallization following anatexis during the Pan-African orogeny. Wilson et al. (2007) argued on the basis of structural evidence and ${ }^{40} \mathrm{Ar} /{ }^{39} \mathrm{Ar}$ ages that the Rauer Group extends southwards from Prydz Bay into the southern Prince Charles Mountains and represents intracratonic deformation during the Pan-African event. Our data indicate that the present metamorphic and structural character of the Prydz Bay region is the result of episodic reactivation between Grenvillian and PanAfrican orogenic activity.

Acknowledgments. We would like to thank the Chinese Arctic and Antarctic Administration for logistic support in the 1992-93, 1998-99, 2001-02 austral summers. Financial support from the National Natural Science Foundation of China (Grants No. 40573039, No.40272081 and 49702033) is gratefully acknowledged. We appreciate the helpful review comments from Simon L. Harley and Ian. S. Williams and our co-editors, Wesley LeMasurier and Alan Cooper.

\section{References}

Black, L.P., Kinny, P.D., Sheraton, J.W., Delor, C.P. (1991). Rapid production and evolution of late Archaean felsic crust in the Vestfold Block of East Antarctica, Precambrian Res., 50, 283-310.
Black, L.P., Kamo, S.L., Allen, C.M., Aleinikoff, J.N., Davis, D.W., Korsch, R.J., Foudoulis, C. (2003), TEMORA 1: a new zircon standard for Phanerozoic U-Pb geochronology, Chem. Geol., 200 , 155-170.

Carson, C.J., Fanning, C.M., Wilson, C.J.L. (1996). Timing of the Progress Granite, Larsemann Hills: evidence for Early Palaeozoic orogenesis within the East Antarctica Shield and implications for Gondwana assembly, Aust. J. Earth Sci., 43, 539-553.

Harley, S.L., Fitzsimons I.C.W. (1991), Pressure-temperature evolution of metapelitic granulites in a polymetamorphic terrane: the Rauer Group, East Antarctica, Journal of Metamorphic Geology, 9, 231-243.

Harley, S.L., Snape, I, Black, L.P. (1998), The evolution of a layered metaigneous complex in the Rauer Group, East Antarctica: evidence for a distinct Archaean terrane, Precambrian Res., 89, 175-205.

Harley, S.L., 1998. Ultrahigh temperature granulite metamorphism $(1050 \mathrm{oC}, 12 \mathrm{kbar})$ metamorphism and decompression in garnet (Mg70)-orthopyroxene-sillimanite gneisses from the Rauer Group, East Antarctica. J. Metamorphic Geology.16, 541-562

Harley, S.L. (2003), Archaean-cambrian crustal development of East Antarctica: metamorphic characteristics and tectonic implications, in Yoshida, M., Windley, B.F., and Dasgupta, S., editors., Proterozoic East Gondwana: Supercontinent Assembly and Breakup: Geological society Special Publications, 206, 203-230.

Hensen, B.J., Zhou, B. (1995), A Pan African granulite facies metamorphic episode in Prydz Bay, Antarctica: evidence from SmNd garnet dating, Australian Journal of Earth Sciences, 42, 249-258.

Hensen, B.J., Zhou, B. (1997), East Gondwana amalgamation by PanAfrican collision? Evidence in the Prydz Bay region, east Antarctica, in The Antarctic Region: Geological Evolution and Processes, edited by C.A Ricci, pp. 115-119, Terra Antarctica Publication, Sienna.

Hokada, T., Harley, S.L., Yokoyama, K. (2003), Peak and post-peak development of UHT metamorphism at Mather Peninsula Rauer Islands: Monazite U-Th-Pb and REE chemistry constraints, In Antarctic Contributions to Global Earth Science (Programme and Abstracts), Ninth International Symposium on Antarctic Earth Sciences. 8-12 September, Potsdam, edited by D.K. Fütterer, pp. 161-162, Potsdam.

Kelsey, D.E., Power, R., Wilson, C.J.L., Steele, D.A. (2003), (Th+U)$\mathrm{Pb}$ monazite ages from Al-Mg-rich metapelites, Rauer Group, east Antarctica, Contrib Mineral Petrol., 146, 326-340.

Kinny, P.D., Black, L.P., Sheraton J.W. (1993), Zircon ages and the distribution of Archean and Proterozoic rocks in the Rauer Islands, Antarctic Science, 5, 193-206.

Kinny, P.D. (1998), Monazite U-Pb ages from east Antarctic granulites: comparisons with zircon U-Pb and garnet Sm-Nd ages, Geological Society of Australia, Abstracts, 49, 250.

Snape, I.S., Black, L.P., Harley, S.L. (1998), Refinement of the timing of magmatism and high-grade deformation in the Vestfold Hills, East Antarctica, from new SHRIMP U-Pb zircon geochronology, in The Antarctic Region: Geological Evolution and Processes, edited by C.A Ricci, pp. 139-148, Terra Antarctica Publication, Sienna.

Tong, L., Wilson, C.J,L. (2006), Tectonothermal evolution of the ultrahigh temperature metapelites in the Rauer Group, east Antarctica, Precambrian Res., 149, 1-20.

Vavra, G., Schmid, R., and D. Gebauer (1999), Internal morphology, habit and $\mathrm{U}-\mathrm{Th}-\mathrm{Pb}$ microanalysis of amphibolite-to-granulite facies zircons: geochronology of the Ivrea Zone (Southern Alps), Contributions to Mineralogy and Petrology, 151, 413-433.

Williams, I. S., Buick, I.S., and I. Cartwright (1996), An extended episode of early Mesoproterozoic metamorphic fluid flow in the Reynolds Range, central Australia, Journal of Metamorphic Geology, 14, 29-47.

Williams I S. (1998), U-Th-Pb Geochronology by Ion Microprobe, in Applications of microanalytical techniques to understanding mineraling processes, edited by McKibben, M.A., Shanks III, W.C., Ridley, W.I., Reviews in Economic Geology. 7, 1- 35.

Wilson, C.J.L., Quinn, C., Tong, L. X, and Phillip, D (2007), Early Palaeozoic intracratonic shears and post-tectonic cooling in the Rauer Group, Prydz Bay, east Antarctica, constrained by ${ }^{40} \mathrm{Ar} /{ }^{39} \mathrm{Ar}$ thermochronology, Antarctic Science., (in press). 